\title{
PERTUMBUHAN DAN SINTASAN BENIH UDANG GALAH (Macrobrachium rosenbergii de Man) PADA PENDEDERAN BERBASIS SISTEM HETEROTROF DENGAN PADAT TEBAR BERBEDA
}

\author{
Ikhsan Khasani dan Asep Sopian \\ Balai Penelitian Pemuliaan Ikan \\ Jl. Raya 2 Sukamandi, Subang 412562 \\ E-mail: ikhsankhasani@yahoo.com
}

(Naskah diterima: 8 Desember 2012; Disetujui publikasi: 22 Agustus 2013)

\begin{abstract}
ABSTRAK
Strategi untuk meningkatkan produksi udang galah dapat ditempuh melalui penyediaan benih unggul dalam jumlah memadai dan berkelanjutan. Penelitian ini bertujuan untuk mendapatkan komponen teknologi pendederan udang galah yang lebih produktif. Teknologi bioflok pada sistem pendederan udang galah, dengan titik berat pada optimasi peran bakteri heterotrof untuk pengendalian senyawa toksik limbah budidaya diharapkan dapat meningkatkan produktivitas melalui peningkatan padat tebar dan sintasan benih. Penelitian menggunakan rancangan acak lengkap dengan tiga tingkat kepadatan benih dan satu kontrol, yang terdiri dari: A) kepadatan 1 ekor/ L, tanpa sistem heterotrof (TSH); B) kepadatan 1 ekor/L dengan sistem heterotrof (SH); C) 2 ekor/ L dengan SH; D) 3 ekor/ L dengan SH, masing-masing perlakuan diulang tiga kali. Sistem heterotrof dijalankan dengan menambahkan molase sebagai sumber karbon dan bakteri Bacillus sp. Hasil yang diperoleh menunjukkan bahwa perlakuan padat tebar dan sistem pengelolaan air memberikan pengaruh nyata $(P<0,05)$ baik terhadap sintasan maupun pertumbuhan benih. Nilai sintasan akhir benih yang diperoleh yaitu $63,3 \pm 13,6 \% 78,0 \pm 22,0 \% 88,7 \pm 8,1 \%$ dan $89,6 \pm 3,7 \%$ berturut- turut untuk perlakuan $A$, B, C, dan D. Hasil yang diperoleh menunjukkan bahwa melalui penerapan teknologi bioflok pendederan udang galah dapat dilakukan tanpa pergantian air dengan kepadatan hingga 3 ekor/L.
\end{abstract}

KATA KUNCI: bioflok, heterotrof, molase, padat tebar, teknologi pendederan, udang galah

ABSTRACT: The growth and survival of giant freshwater prawn seed (Macrobrachium rosenbergii de Man) in nursery based heterotrophic system in different seed density. By: Ikhsan Khasani and Asep Sopian

The strategy to increase productivity of giant freshwater prawn can be done by supply both quality and quantity of prawn seed. The aim of this study was to create technology component to increase productivity of prawn nursery. Biofloc technology, focusing on optimize heterotrophic bacteria as remediation agent was applied to maintain water quality. Complete randomize design was used in the study with three different density level of seed and control, there were A) 1 seed/L in non heterotrophic system (NHS); B) 1 seed/L in HS; C) 2 seeds/L in HS; and D. 3 seeds/L in HS, each tretment in 3 replicates. The result showed that survival and growth of prawn seed in all treatment was different $(P<0.05)$. The survival rate of seed were $63.3 \pm 13.6 \% ; 8.0$ $\pm 22.0 \%: 88.7 \pm 8.1 \% ;$ and $89.6 \pm 3.7 \%$ for $A, B, C$, and $D$, respectively. The result suggested 
that biofloct technology can be applicated in prawn nursery with good performance until 3 seeds/ L.

\section{KEYWORDS: biofloc, density, giant freshwater prawn, heterotroph, mollase, nursery}

\section{PENDAHULUAN}

Guna mendukung upaya peningkatan produktivitas budidaya udang galah diperlukan ketersediaan benih siap tebar dalam jumlah memadai dan berkelanjutan. Salah satu upaya dalam menyediakan benih dengan ketahanan tinggi terhadap kondisi lingkungan kolam dan tambak yang fluktuatif, serta berisiko kecil terhadap predator adalah dengan penyediaan benih ukuran tokolan (Alston \& Sampaio, 2000; Khasani, 2006), yang diperoleh melalui kegiatan pendederan (nursery). Benih ukuran tokolan juga diperlukan dalam pengembangan sistem budidaya udang galah di lahan sawah, yang dikenal dengan Paduga (padi- udang galah).

Intensifikasi pendederan melalui peningkatan padat tebar benih dan penggunaan pakan berprotein tinggi dilakukan guna meningkatkan produksi benih per satuan luas. Kegiatan tersebut ternyata cukup berisiko apabila kurang tepat dalam pengelolaannya, karena menghasilkan bahan organik dalam jumlah besar yang memacu peningkatan kadar senyawa toksik seperti amonia dan nitrit, serta perkembangan bakteri patogen. Limbah organik, baik dalam bentuk terlarut (dissolved) maupun padatan (suspended) juga berpotensi menurunkan daya dukung perairan bagi kehidupan organisme akuatik dan masyarakat apabila tidak dikelola dengan baik.

Limbah cair akuakultur diketahui memiliki kandungan unsur nitrogen terlarut sangat tinggi, dalam bentuk amonia, nitrit, dan nitrat (Summerfelt et al., 2001; Brune et al., 2003) yang apabila dibuang langsung ke perairan umum atau digunakan kembali ke kolam budidaya dapat menyebabkan kematian ikan serta eutrofikasi yang menyebabkan gangguan ekosistem. Di sisi lain, nutrien yang terkandung tersebut berpotensi sebagai media bagi pengembangan pakan alami yang dapat menambah nilai ekonomis limbah tersebut (Crab et al., 2012). Selain itu, populasi mikroorganisme yang ada dalam limbah cair diprediksi dapat menjadi makanan alami bagi benih udang galah selama pendederan, dikarenakan ketersediaan pakan alami pada kolam pendederen berpengaruh nyata terhadap pertumbuhan benih udang galah (Khasani, 2006).

Kajian sistem bioflok pada udang galah telah dilakukan oleh Crab et al. (2009a). Pengujiaan pemberian bioflok untuk nutrisi benih udang galah sekala laboratorium memperlihatkan bahwa benih udang galah mampu memanfaatkan bioflok sebagai satusatunya sumber nutrien. Rohmana (2008) juga menyatakan bahwa benih udang galah ukuran yuwana $(1,07 \mathrm{~g})$ mampu memanfaatkan bakteri heterotrof (bioflok) yang dihasilkan dari penggabungan limbah nitrogen budidaya ikan lele dengan molases sebagai sumber karbon organik.

Dalam kegiatan ini telah dilakukan pendederan udang galah sistem hemat air melalui aplikasi teknologi heterotrof, guna mendukung sistem budidaya perikanan yang lebih produktif dan berkelanjutan.

\section{BAHAN DAN METODE}

Penelitian dilakukan di hatcheri udang galah Balai Penelitian Pemuliaan Ikan Sukamandi, Subang, Jawa Barat.

Guna mengoptimalkan kondisi pendederan, corong pemeliharaan benih udang disucihamakan dengan cara merendam dalam larutan natrium hipoklotit (kaporit) dosis 20 $\mathrm{mg} / \mathrm{L}$ (bahan aktif 60\%. Batu aerasi, alat bantu dan selang aerasi juga direndam dalam larutan kaporit dosis $20 \mathrm{mg} / \mathrm{L}$. Air sumur disaring dengan saringan kapas, selanjutnya dikaporit dengan dosis $10 \mathrm{~g} / \mathrm{L}$ (60\%bahan aktif). Guna mereduksi residu klorin dilakukan aerasi secara kuat selama 48 jam, selanjutnya dilakukan cek residu klorin dengan test kit residu klorin (Merck).

Seleksi benih dilakukan dengan merendam benih, pasca larva umur 10-15 hari dengan ukuran panjang total rata- rata $9,16 \pm 0,8 \mathrm{~mm}$ dan bobot $0,015 \pm 0,006 \mathrm{~g}$ dengan umur sama (PL- 10), dalam larutan formalin 300 mg/ L selama satu menit, dengan tujuan mendapatkan benih sehat dan bebas dari organisme parasit. Benih udang dipelihara dalam wadah gelas serat 
volume $60 \mathrm{~L}$ yang diisi $50 \mathrm{~L}$ air tawar steril. Perlakuan yang digunakan adalah padat tebar awal benih, yaitu: A) padat tebar 1 ekor/ L tanpa penambahan molase dan bakteri; B) padat tebar 1 ekor/L dengan penambahan molase dan bakteri, C) padat tebar 2 ekor/ $L$ dengan penambahan molase dan bakteri, dan D) padat tebar 3 ekor/L dengan penambahan molase dan bakteri. Masing- masing perlakuan diulang tiga kali. Pemeliharaan dilakukan selama 28 hari tanpa ganti air. Suplai oksigen dilakukan dengan memasang instalasi aerasi secara merata sehingga kadar oksigen terlarut optimal yaitu $>5 \mathrm{mg} / \mathrm{L}$ (Crab et al., 2009 ${ }^{\mathrm{b}}$ ). Dua buah naungan (shelter) berbahan plastik ukuran $30 \mathrm{~cm} \times 50 \mathrm{~cm}$ ditempatkan di setiap perlakuan guna meningkatkan luasan bagi benih udang dan mengurangi kanibalisme terhadap benih yang sedang ganti kulit (moulting).

Pakan yang digunakan adalah pakan udang dengan kandungan protein $27,88 \%$ (hasil analisa PAU IPB), sedangkan molase yang digunakan mengandung kadar $\mathrm{C}$ total sebesar 27,88\%dan kadar air 52\% Pakan udang diberikan dengan jumlah sesuai Alston \& Sampaio (2000), 20\%biomassa udang pada bulan pertama, diberikan pada pagi, siang, dan sore. Molase steril, sebagai sumber karbon organik diberikan dengan jumlah sesuai Goldman et al (1987) dalam Azim \& Little (2008); Avnimelech (2007); Crab et al. (2009 $)$ sehingga rasio C:N minimal 20, diberikan setiap hari setelah pemberian pakan terakhir. Natrium silikat dengan dosis $1 \mathrm{mg} / \mathrm{L}$ diberikan selama tujuh hari sebagai sumber mikro nutrien bagi bakteri (Rohmana, 2008). Inokulasi $1 \mathrm{~mL}$ biakan bakteri Bacillus sp. (densitas $3 \times 10^{13} \mathrm{cfu} / \mathrm{mL}$ ), dilakukan guna mempercepat pembentukan bioflok dan mengendalikan tumbuhnya bakteri patogen. Penyiponan hanya dilakukan pada perlakuan A saja, yang bertujuan untuk mengurangi sisa pakan. Penambahan air dilakukan sebanyak volume air saat penyiponan.

Paramater biologis yang diamati adalah pertumbuhan udang, meliputi panjang standar dan bobot badan, pengamatan dilakukan tiap tujuh hari. Sintasan udang diamati pada hari ke- 14 dan 28. Kelimpahan bakteri heterotrof diamati setiap dua minggu, dengan metode Total Plate Count menggunakan teknik sebar pada media Tryptose Soya Agar (TSA) sesuai Cappucino \& Sherman (2001). Bakteri yang dominan dianal isa secara morfologi biokimiawi di Balai Uji Standarisasi Karantina Ikan, Jakarta dan dianalisis sesuai Holt et al. (1994).
Pengukuran parameter kualitas air utama, kadar amonia, dan nitrit dilakukan setiap minggu dengan metode phenate dan sulphanilamit, dengan alat baca spektrofotometer (APHA, 2005). Parameter kualitas air pendukung yang diamati adalah suhu, $\mathrm{pH}$, oksigen terlarut, diukur setiap minggu menggunakan digital water quality checker. Alkalinitas total diukur dengan titrasi asam sesuai APHA (2005).

Data fisika-kimia air media pendederan dan populasi bakteri heterotrof dianalisis secara deskriptif. Pertumbuhan dan sintasan udang galah dianalisis secara statistik dengan program SPSS 17 dan minitab 13 (Mattjik \& Sumentajaya, 2006).

\section{HASIL DAN BAHASAN}

Pengujian pendederan benih udang galah dengan menerapkan sistem heterotrof dengan padat penebaran benih berbeda telah menghasilkan data panjang, bobot, dan sintasan benih sebagaimana yang tertuang pada Gambar 1 dan 2 serta Tabel 1.

Bobot benih udang galah hingga hari ke14 antara perlakuan A, C, dan D nampak sama, sekitar 0,065 g. Pada hari ke- 21, terlihat bahwa benih pada perlakuan $\mathrm{D}$, dengan kepadatan tertinggi, mulai lambat pertumbuhannya. Namun demikian, secara statistik bobot yang dicapai setelah 28 hari pemeliharaan tidak menunjukkan perbedaan nyata. Bobot ratarata benih pada akhir pengamatan adalah $0,15 \pm 0,04 \mathrm{~g} ; 0,15 \pm 0,02 \mathrm{~g} ; 0,13 \pm 0,02 \mathrm{~g}$, dan $0,12 \pm 0,02 \mathrm{~g}$, berturut- turut untuk perlakuan A, B, C, dan D.

Garis kurva pertumbuhan keempat perlakuan pada karakter panjang standar nampak berhimpit hingga akhir pengujian, dan setelah diuji statistik juga tidak memperlihatkan perbedaan yang nyata hingga akhir penelitian. Panjang standar benih udang galah yang diperoleh sebesar 15,7 $\pm 0,85 \mathrm{~mm} ; 16,10 \pm$ $0,56 \mathrm{~mm} ; 16,03 \pm 0,87 \mathrm{~mm}$; dan 15,83 $\pm 0,81$ $\mathrm{mm}$, berturut- turut untuk perlakuan $\mathrm{A}, \mathrm{B}, \mathrm{C}$, dan D.

Pertumbuhan, baik pertambahan bobot maupun panjang merupakan salah satu indikator berfungsinya sistem metabolisme. Dalam kondisi lingkungan optimal dan kebutuhan nutrisi tercukupi maka benih akan tumbuh secara optimal pula, dan sebaliknya. Data panjang dan bobot benih yang diperoleh dalam empat kali waktu sampling menunjukkan pola pertumbuhan linier. Hal tersebut 


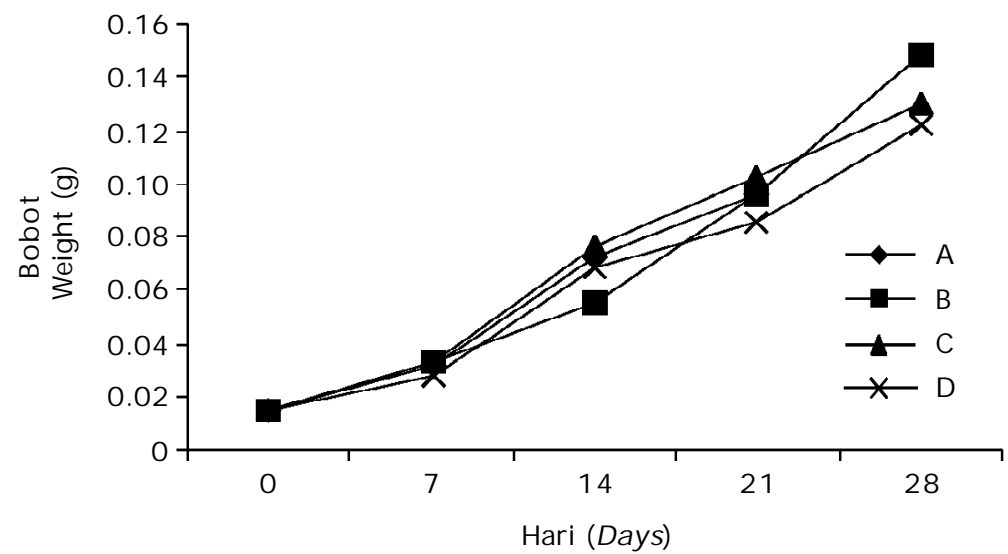

Keterangan (Note):

A. Tanpa sistem heterotrof (TSH), kepadatan 1 ekor/L; B. Sistem heterotrof (SH) dengan 1 ekor/L; C. SH, 2 ekor/L; D. SH, 3 ekor/L (A. Non heterotrophic system (NHS), density 1 seed/L; B. Heterotroph system (HS), 1 seed/L; C. HS, 2 seed/L; D. HS, 3 seed/L)

Gambar 1. Perkembangan bobot benih udang galah selama 28 hari pemeliharaan

Figure 1. The development of prawn seed weight during 28 days nursery system

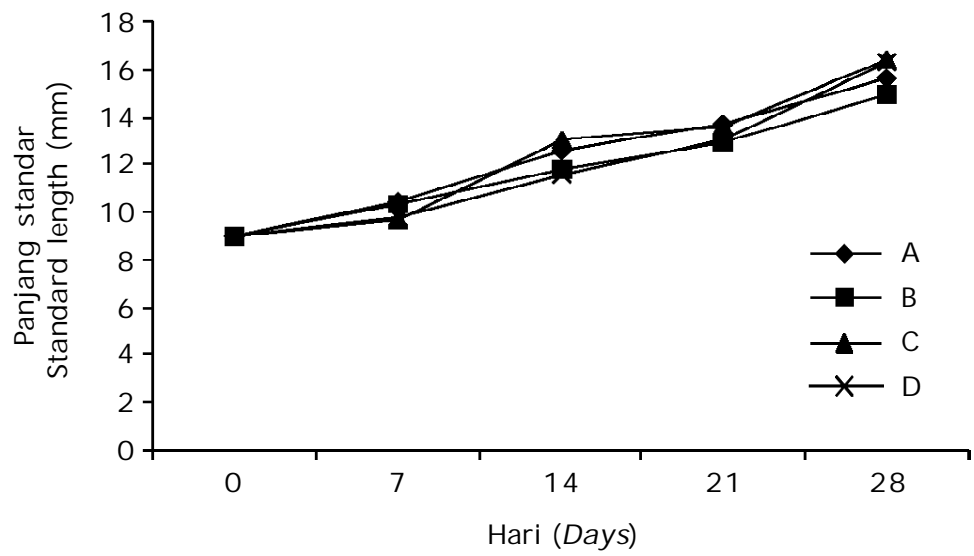

Keterangan (Note):

A. Tanpa sistem heterotrof (TSH), kepadatan 1 ekor/L; B. Sistem heterotrof (SH) dengan 1 ekor/ L; C. SH, 2 ekor/L; D. SH, 3 ekor/L (A. Non heterotrophic system (NHS), density 1 seed/ L; B. Heterotroph system (HS), 1 seed/L; C. HS, 2 seed/L; D. HS, 3 seed/L)

Gambar 2. Perkembangan panjang benih udang galah selama 28 hari pemeliharaan

Figure 2. The development of total lenght of prawn seed during 28 days nursery system

menggambarkan bahwa kondisi lingkungan dan nutrisi pada keempat perlakuan masih mampu mendukung sistem metabolisme benih.

\section{Sintasan}

Sintasan benih udang galah yang dipelihara selama 28 hari pada sistem heterotrof dengan padat tebar benih berbeda disajikan pada Tabel 1.

Sintasan yuwana udang galah pada 14 hari pemeliharaan nampak berbeda nyata $(P<0,05)$ antara perlakuan $\mathrm{A}$, tan pa penambahan bakteri dan molase, dengan perlakuan B, C, dan D. Hal tersebut menunjukkan bahwa kondisi ling- 
Tabel 1. Sintasan benih udang galah selama pendederan

Table 1. Survival rate of prawn seeds during nursery

\begin{tabular}{cccc}
\hline $\begin{array}{c}\text { Perlakuan } \\
\text { Treatment }\end{array}$ & $\begin{array}{c}\text { Jumlah awal } \\
\text { Seed total } \\
\text { Ekor (Prawn) }\end{array}$ & $\begin{array}{c}\text { Sintasan rata-rata } \\
\text { Average survival rate } \\
\text { H-14 (14 }\end{array}$ (1) $^{\text {day) }} \mathbf{( \% )}$ & $\begin{array}{c}\text { Sintasan rata-rata } \\
\text { Average survival rate } \\
\text { H-28 (28 }\end{array}$ \\
\hline A & 50 & $70.7 \pm 15^{\mathrm{a}}$ & $63.3 \pm 14^{\mathrm{a}}$ \\
B & 50 & $94.0 \pm 10^{\mathrm{b}}$ & $78.0 \pm 22^{\mathrm{b}}$ \\
C & 100 & $95.0 \pm 3^{\mathrm{b}}$ & $88.7 \pm 8^{\mathrm{ab}}$ \\
D & 150 & $95.3 \pm 4^{\mathrm{b}}$ & $89.5 \pm 4^{\mathrm{b}}$ \\
\hline
\end{tabular}

Keterangan (Notes):

A. Tanpa sistem heterotrof (TSH), kepadatan 1 ekor/ L; B. Sistem heterotrof (SH) dengan 1 ekor/ L;

C. SH, 2 ekor/L; D. SH, 3 ekor/L (A. Non heterotrophic system (NHS), density $1 \mathrm{seed} / \mathrm{L}$;

B. Heterotroph system (HS), 1 seed/L; C. HS, 2 seed/L; D. HS, 3 seed/L)

kungan dan ketersediaan nutrisi pada sistem heterotrof lebih kondusif bagi benih udang galah. Demikian pula pada akhir pengujian, perlakuan sistem heterotrof masih memberikan hasil yang nyata lebih baik dari kontrol. Nilai sintasan yang cenderung tinggi pada perlakuan $C$ dan $D$ memberi harapan besar bahwa melalui penerapan sistem heterotrof produktivitas pendederan dapat ditingkatkan.

Pada pendederan udang galah sistem standar, sistem ganti air atau resirkulasi, secara indoor selama 60 hari diperoleh sintasan sebesar 60-90\% (Alston \& Sampaio, 2000; Khasani, 2006). Kegiatan sampling benih udang yang dilakukan secara periodik tiap dua minggu mengindikasikan bahwa populasi benih udang galah pada perlakuan A sudah mengalami penurunan setelah dua minggu pemeliharaan. Hal tersebut menunjukkan bahwa daya dukung media pemeliharaan benih sudah mengalami penurunan.

Salah satu faktor yang menyebabkan kematian pada pendederan udang galah dengan kepadatan tinggi adalah faktor kanibalisme, udang sehat memangsa udang yang ganti kulit (Coyle et al., 2010). Kematian juga biasanya diakibatkan oleh kurang mendukungnya lingkungan pemeliharaan, adanya infeksi penyakit, maupun kekurangan nutrisi dalam waktu cukup lama (Server et al., 1982 dalam Alston \& Sampaio, 2000). Nilai sintasan yang tinggi pada semua perlakuan sistem heterotrof hingga hari14 menunjukkan bahwa sistem tersebut mampu menyediakan lingkungan yang nyaman bagi benih udang galah. Tingkat sintasan yang masih tinggi pada perlakuan $D$, dengan kepadatan 3 ekor/L merupakan gambaran bahwa daya dukung (carring capacity) wadah pendederan masih memadai dan mampu menekan tingkat kompetisi ruang antar benih.

\section{Parameter Fisika- Kimia Air}

Kisaran parameter fisika- kimia air, yang meliputi suhu, oksigen terlarut (DO: Dissolved Oxygen), $\mathrm{pH}$, alkalinitas, total amonia nitrogen (TAN) dan nitrit ditampilkan pada Tabel 2.

Data parameter kualitas air pada Tabel 2. menggambarkan bahwa selama kegiatan penelitian sebagian besar parameter kualitas air seperti oksigen terlarut, suhu, pH, TAN dan nitrit dalam kisaran optimum bagi kehidupan benih udang galah. Secara umum, parameter kualitas air optimal bagi kehidupan udang galah adalah suhu air $26^{\circ} \mathrm{C}-32^{\circ} \mathrm{C}$, oksigen terlarut 3- $7 \mathrm{mg} / \mathrm{L}$; kesadahan 30- $150 \mathrm{mg} / \mathrm{L}$; pH 7,0-8,5, kecerahan $25-40 \mathrm{~cm}$, alkalinitas $\left(\mathrm{CaCO}_{3}\right) \mathrm{100} / \mathrm{L}$, amonia non ion $\left(\mathrm{NH}_{3}{ }^{-}\right)$0,1-0,3 mg/ L (New, 1995; D'Abramo et al., 1995; Boyd \& Zimmermann 2000; Wynne, 2000; Coyle et al., 2010). Meskipun nilai alkalinitas melebihi kisaran optimal bagi yuwana udang galah namun menurut Coyle et al., 2010 pada level tersebut belum berdampak terhadap performa tumbuh benih udang galah. Pertumbuhan juvenil udang galah akan terhambat pada level alkalinitas $8205 \mathrm{mg} / \mathrm{L}$.

\section{Kadar Amonia}

Dinamika kadar total amonia nitrogen (TAN) selama pengujian pendederan sistem heterotrof dengan padat tebar benih berbeda dituangkan pada Gambar 3. Kadar amonia cenderung meningkat seiring waktu peme- 
Tabel 2. Parameter kualitas air pemeliharaan benih udang galah selama pemeliharaan Table 2. Water quality parameters of seed culture media during nursery period

\begin{tabular}{ccccccc}
\hline $\begin{array}{c}\text { Perlakuan } \\
\text { Treatment }\end{array}$ & $\begin{array}{c}\text { DO } \\
(\mathbf{m g} / \mathbf{L})\end{array}$ & $\begin{array}{c}\text { Temperature } \\
\mathbf{( { } ^ { \circ } \mathbf { C } )}\end{array}$ & $\mathbf{p H}$ & $\begin{array}{c}\text { Alkalinitas } \\
\text { Acalinity } \\
\mathbf{( m g / L )}\end{array}$ & $\begin{array}{c}\text { TAN } \\
(\mathbf{m g} / \mathbf{L})\end{array}$ & $\begin{array}{c}\mathbf{N O} \\
\mathbf{( m g / L )}\end{array}$ \\
\hline A & $7.8-8.0$ & $26.3-28.4$ & $7.9-8.2$ & $140-160$ & $0.001-0.3$ & $0.001-0.2$ \\
B & $7.6-8.1$ & $26.3-28.8$ & $8.1-8.2$ & $160-180$ & $0.001-0.2$ & $0.001-0.2$ \\
C & $7.2-8.0$ & $26.3-28.7$ & $7.9-8.2$ & $160-170$ & $0.001-0.3$ & $0.001-0.3$ \\
D & $7.1-7.4$ & $26.3-28.9$ & $7.9-8.3$ & $150-170$ & $0.001-0.3$ & $0.001-0.3$ \\
\hline
\end{tabular}

Keterangan (Notes):

A. Tanpa sistem heterotrof (TSH), kepadatan 1 ekor/ L; B. Sistem heterotrof (SH) dengan 1 ekor/ L; C. SH, 2 ekor/L; D. SH, 3 ekor/L (A. Non heterotrophic system (NHS), density 1 seed/L; B. Heterotroph system (HS), 1 seed/L; C. HS, 2 seed/L; D. HS, 3 seed/L)

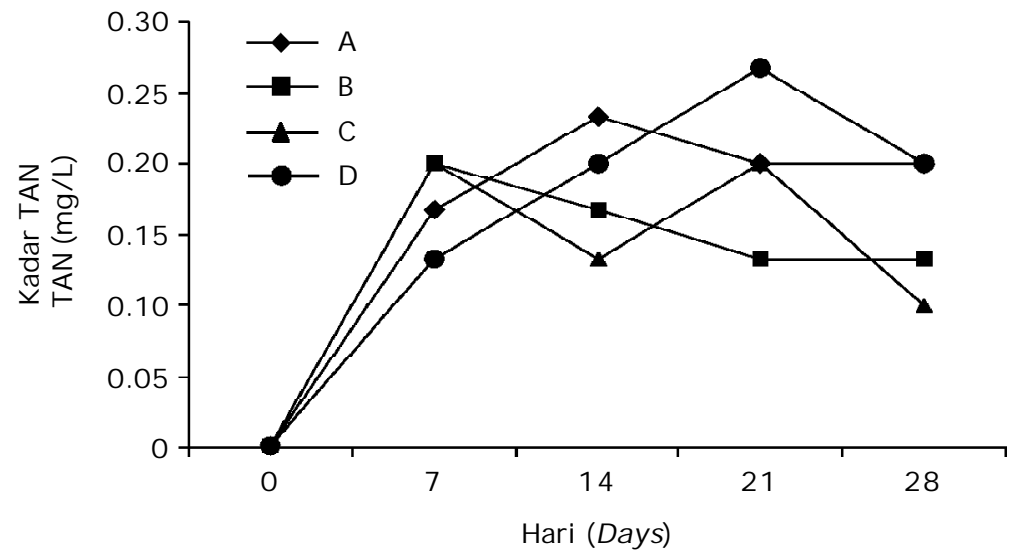

Keterangan (Note):

A. Tanpa sistem heterotrof (TSH), kepadatan 1 ekor/L; B. Sistem heterotrof (SH) dengan 1 ekor/L; C. SH, 2 ekor/L; D. SH, 3 ekor/L (A. Non heterotrophic system (NHS), density 1 seed/L; B. Heterotroph system (HS), 1 seed/L; C. HS, 2 seed/L; D. HS, 3 seed/L)

Gambar 3. Dinamika kadar amonia total (TAN) media pendederan selama pengujian

Figure 3. The TAN dynamic in nursery media during study

liharaan udang dan bertambahnya sisa metabolisme udang. Hal tersebut mengindikasikan bahwa sistem heterotrof, yang diharapkan dapat mengonversi amonia menjadi biomassa bakteri, belum bekerja optimal sesuai yang diharapkan. Kadar amonia yang relatif tinggi dengan level $\mathrm{pH}>8$ pada minggu keenam diprediksi sebagai penyebab rendahnya sintasan benih, yaitu menyebabkan kematian sebagian udang yang sedang ganti kulit dan berada di dasar bak pemeliharaan dengan kadarTAN lebih tinggi. Pada $\mathrm{pH}$ tinggi persentase amonia dalam bentuk non- ion (unionized amonia, $\mathrm{NH}_{3}{ }^{-}$) yang sangat toksik bagi udang galah juga tinggi. Robinette \& Heinen (1991) dalam New (1995) menyatakan bahwa pemeliharaan benih udang galah pada level $\mathrm{pH}$ 8,59,0 kadar TAN tidak boleh lebih dari $1 \mathrm{mg} / \mathrm{L}$ dan pada $\mathrm{pH} 8$ kadar TAN maksimal sebesar 2 $\mathrm{mg} / \mathrm{L}$.

Amonia merupakan senyawa toksik bagi semua hewan akuatik, terlebih bagi udang galah yang mengalami ganti kulit. Kadar amonia media yang tinggi akan meningkatkan kadar amonia darah sehingga $\mathrm{pH}$ darah naik. Dalam kondisi demikian, osmoregulasi terganggu, konsumsi oksigen oleh jaringan meningkat, 
dan transpor oksigen ke darah menurun, sehingga pertumbuhan udang terganggu dan dalam kondisi ekstrim berakibat kematian (Noga, 2000).

\section{Kadar Nitrit}

Nitrit juga merupakan senyawa yang sangat toksik bagi benih udang galah, khususnya selama ganti kulit. Dinamika kadar nitrit selama pengujian pendederan sistem heterotrof dengan perlakuan pemberian jumlah pakan berbeda dituangkan pada Gambar 4. Kadar nitrit mengalami fluktuasi, pada minggu pertama kadar nitrit mengalami kenaikan sangat drastis hingga $0,2 \mathrm{mg} / \mathrm{L}$. Pada pengamatan minggu ketiga kadar nitrit turun cukup drastis dan bertahan dalam level rendah hingga minggu keenam. Namun demikian, kadar nitrit pada minggu ketujuh dan kedelapan kembali meningkat. Kadar nitrit yang disarankan untuk kehidupan udang galah adalah di bawah 0,1 $\mathrm{mg} / \mathrm{L}$ (New, 2002), namun demikian Mallasen \& Valenti (2006) menyatakan bahwa udang galah relatif resisten terhadap nitrit sehing ga pada media hingga $2 \mathrm{mg} / \mathrm{L}$ pertumbuhan dan sintasan benih udang galah belum terpengaruh nyata.

Secara umum, nitrit merupakan senyawa toksik bagi sebagian hewan akuatik, khususnya yang dipelihara dalam media air tawar dengan kandungan klorid rendah. Nitrit secara aktif diangkut melewati insang dan masuk ke dalam sistem peredaran darah, selanjutnya mengoksidasi hemoglobin menjadi metemoglobin. Metemoglobin tidak dapat mengangkut oksigen secara efektif sehingga jaringan kekurangan oksigen (Noga, 2000).

\section{Dinamika Populasi Bakteri}

Bakteri merupakan komponen utama yang diharapkan bekerja pada sistem heterotrof, karena waktu regenerasi (generating time) yang cepat. Inokulasi bakteri diharapkan mampu mempercepat pembentukan bioflok sehingga mekanisme biodegradasi dan biokonversi limbah organik dan senyawa nitrogen yang toksik menjadi biomasa mikroorganisme berjalan lebih cepat. Melalui penambahan bakteri positif dalam media pemeliharaan udang diharapkan pula dapat menekan potensi bakteri patogen untuk berkembang.

Selama delapan minggu pengujian dan dilakukan pengamatan dinamika populasi bakteri heterotrof aerobik, diperoleh data sesuai Tabel 3.

Data populasi bakteri pada Tabel 3 menggambarkan bahwa densitas bakteri pada semua perlakuan relatif sama yaitu pada kisaran $10^{7}-10^{9} \mathrm{cfu} / \mathrm{mL}$. Data tersebut menunjukkan bahwa pada sistem pendederan tanpa ganti air, populasi bakteri heterotrof

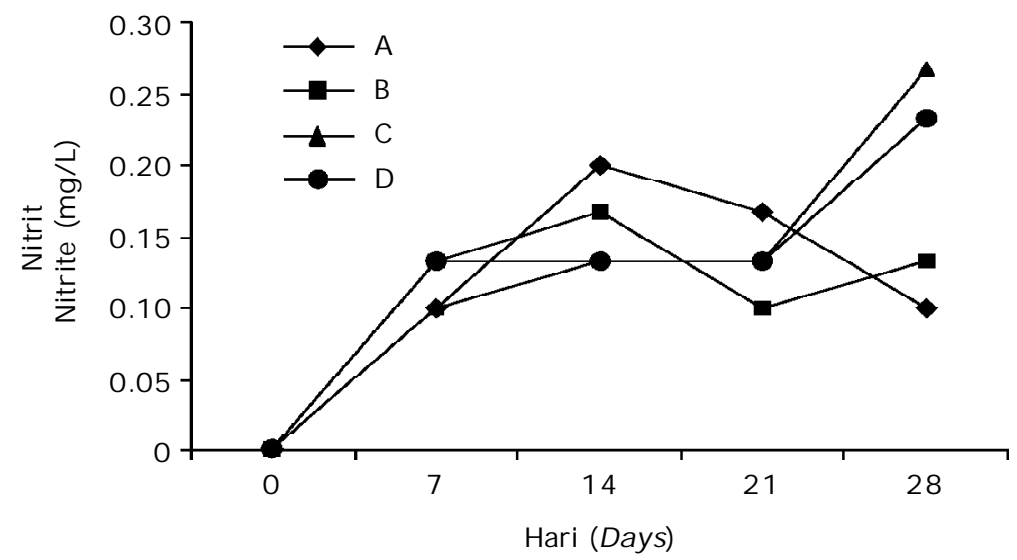

Keterangan (Note):

A. Tanpa sistem heterotrof (TSH), kepadatan 1 ekor/ L; B. Sistem heterotrof (SH) dengan 1 ekor/L; C. SH, 2 ekor/L; D. SH, 3 ekor/ L (A. Non heterotrophic system (NHS), density 1 seed/L; B. Heterotroph system (HS), 1 seed/L; C. HS, 2 seed/L; D. HS, 3 seed/L)

Gambar 4. Dinamika kadar nitrit media pendederan selama penelitian

Figure 4. The nitrite dynamic in nursery media during study 
Tabel 3. Populasi bakteri pada kolom air pendederan udang galah selama 28 hari

Table3. The bacteria population in water column of prawn seed nursery during 28 days

\begin{tabular}{ccccc}
\hline \multirow{2}{*}{$\begin{array}{c}\text { Perlakuan } \\
\text { Treatment }\end{array}$} & \multicolumn{4}{c}{ Jumlah koloni bakteri (Total of bacteria colony ) (cfu/ mL) } \\
\cline { 2 - 5 } & $\begin{array}{c}\text { Awal } \\
\text { Initial }\end{array}$ & $\begin{array}{c}\text { Hari-7 } \\
7^{\text {th }} \text { day }\end{array}$ & $\begin{array}{c}\text { Hari-21 } \\
21^{\text {th }} \text { day }\end{array}$ & $\begin{array}{c}\text { Hari-29 } \\
29^{\text {th }} \text { day }\end{array}$ \\
\hline A1 & 0 & $1.6 \times 10^{6}$ & $1.0 \times 10^{7}$ & $1.0 \times 10^{6}$ \\
A2 & 0 & $3.75 \times 10^{7}$ & $4.0 \times 10^{7}$ & $1.2 \times 10^{6}$ \\
A3 & 0 & $6.9 \times 10^{6}$ & $3.3 \times 10^{6}$ & $1.2 \times 10^{6}$ \\
B1 & $6.1 \times 10^{8}$ & $6.5 \times 10^{8}$ & $3.8 \times 10^{6}$ & $3.0 \times 10^{9}$ \\
B2 & $6.1 \times 10^{8}$ & $7.5 \times 10^{8}$ & $1.2 \times 10^{6}$ & $1.2 \times 10^{6}$ \\
B3 & $6.1 \times 10^{8}$ & $5.0 \times 10^{8}$ & $1.4 \times 10^{7}$ & $6.0 \times 10^{7}$ \\
C1 & $6.1 \times 10^{8}$ & $2.0 \times 10^{8}$ & $1.2 \times 10^{6}$ & $6.0 \times 10^{6}$ \\
C2 & $6.1 \times 10^{8}$ & $1.0 \times 10^{8}$ & $1.0 \times 10^{6}$ & $2.0 \times 10^{7}$ \\
C3 & $6.1 \times 10^{8}$ & $1.0 \times 10^{8}$ & $3.2 \times 10^{6}$ & $1.4 \times 10^{8}$ \\
D1 & $6.1 \times 10^{8}$ & $4.5 \times 10^{8}$ & $1.3 \times 10^{6}$ & $1.4 \times 10^{6}$ \\
D2 & $6.1 \times 10^{8}$ & $1.0 \times 10^{8}$ & $3.0 \times 10^{6}$ & $1.2 \times 10^{7}$ \\
D3 & $6.1 \times 10^{8}$ & $2.0 \times 10^{8}$ & $8.1 \times 10^{6}$ & $4.9 \times 10^{6}$ \\
\hline
\end{tabular}

cenderung tinggi dikarenakan ada sisa pakan dan ekskresi udang. Pada sistem bioflok yang berjalan baik komunitas mikroba (bakteria) dapat mencapai $10^{7} \mathrm{cfu} / \mathrm{mL}$ (Burford et al., 2003 dalam Avnimelech, 2007). Akan tetapi, data volume flok menunjukkan nilai yang mencolok berbeda dan cenderung berban- ding lurus dengan jumlah udang dan pakan yang diberikan. Data volume flok ditampilkan pada Gambar 5.

Pada shelter plastik yang dipasang secara melintang di bak nampak secara jelas terbentuknya lendir dan lapisan yang menutupi

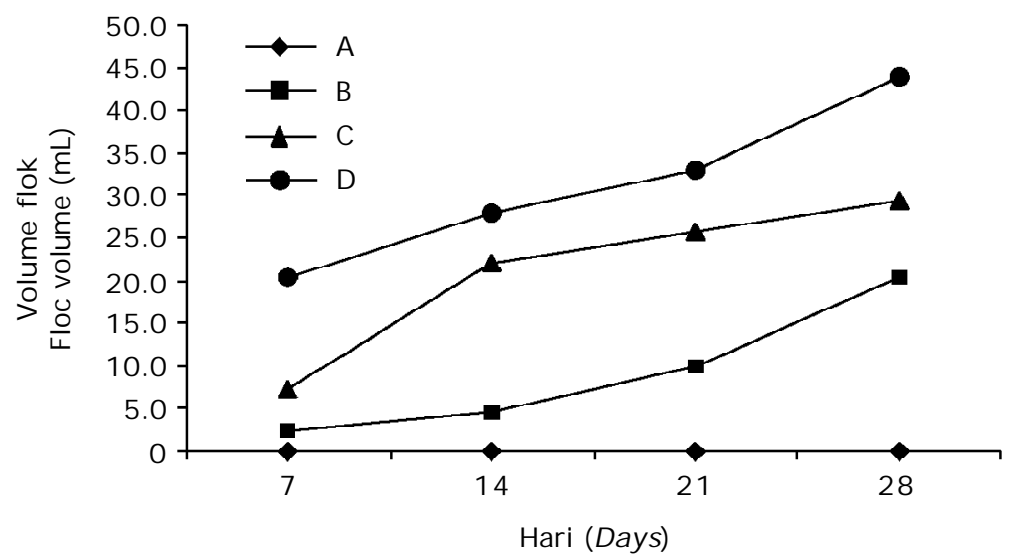

Keterangan (Note):

A. Tanpa sistem heterotrof (TSH), kepadatan 1 ekor/L; B. Sistem heterotrof (SH) dengan 1 ekor/ L; C. SH, 2 ekor/L; D. SH, 3 ekor/L (A. Non heterotrophic system (NHS), density 1 seed/L; B. Heterotroph system (HS), 1 seed/L; C. HS, 2 seed/L; D. HS, 3 seed/L)

Gambar 5. Volume flok pada media pendederan selama pengujian

Figure 5. Floc volume in nursery media during study 
rongga shelter. Secara visual ketebalan lapisan "koloni mikroorganisme, berbanding lurus dengan jumlah pakan yang diberikan. Lapisan tersebut diprediksi tersusun atas mikroorganisme, antara lain bakteria, fungi, mikro alga, dan protozoa. Organisme penempel atau perifiton diketahui dapat dikonsumsi oleh beberapa spesies ikan dan udang, di antaranya udang galah. Pengamatan secara mikroskopis air media pendederan menunjukkan bahwa kelimpahan protozoa pada masing- masing perlakuan cenderung meningkat seiring kepadatan dan terkait jumlah pakan yang diberikan, yaitu 2,33 $\pm 0,58$ ekor/ $\mathrm{mL} ; 4,33 \pm 1,15$ ekor/mL; 8,67 1 1,5 ekor/mL; dan 12,5 $\pm 2,5$ ekor/ $\mathrm{mL}$, berturut- turut untuk perlakuan $\mathrm{A}, \mathrm{B}$, $C$, dan D. Hasil identifikasi terhadap organisme tersebut menunjukkan bahwa protozoa tersebut adalah jenis Monostyla sp. Karakter bakteri yang dominan tumbuh pada media pendederan udang galah, yaitu warna koloni krem, bentuk batang, dengan tepi koloni rata. Hasil analisis morfologi biokimiawi isolat tersebut mengarah pada species Bacillus sp.

\section{KESIMPULAN}

Penerapan sistem heterotrof, melalui penambahan bakteri dan sumber karbon organik, mampu mempertahankan kondisi lingkungan media pendederan udang galah sehingga udang dapat tumbuh normal dengan sintasan tinggi.

Dengan menerapkan sistem heterotrof, produktivitas pendederan dapat ditingkatkan dengan meningkatkan kepadatan awal benih hingga 3 ekor/L atau setara 3.000 ekor/ton media.

\section{DAFTARACUAN}

Alston, D.E. \& Sampiao, C.M.S. 2000. Nursery sistem and management. Dalam: New, M.B. \&W.C. Valenti. 2000. Freshwater prawn culture: The farming of Macrobrachium rosenbergii. Blackwell Science, Oxford: xix $+435 \mathrm{pp}$.

APHA. 2005. Standard methods for the examination of water $\&$ wastewater $21^{\text {st }}$ edition. APHA AWWA WEF, Washington: xxxvii + 1,207 pp.

Avnimelech, Y. 2007. Feeding with microbial flocs by tilapia in minimal discharge bioflocs technology ponds. Aquaculture, 264: 140- 147.

Azim, M.E. \& Little, D.C. 2008. The biofloc technology (BFT) in indoor tanks: Water quality, biofloc composition, and growth and welfare of Nile tilapia (Oreochromis niloticus). Aquaculture, 283: 29- 35.

Boyd, C. \& Zimmermann, S. 2000. Grow- out Systems-Water Quality and Soil Management. Dalam: New, M.B. \& W.C. Valenti. 2000. Freshwater prawn culture: The farming of Macrobrachium rosenbergii. Blackwell Science, Oxford: $x i x+435$ pp.

Brune, D.E. , Schwartz, G., Eversole, A.G., Collier, J.A., \& Schwedler, T.E. 2003. Intensification of pond aquaculture and high rate photosynthetic systems. Aquacultural Engineering, 28: 65- 86.

Cappuccino, J.G. \&Sherman, N. 2001. Microbiology: a laboratory manual. Benjamin Cummings, San Fransisco, xv + 489 pp.

Coyle, S.D., Alston, D.E., \& Sampiao, C.M.S. 2010. Nursery system and management. Dalam: New, M.B., W.C. Valenti, J.H. Tidwell, L.R. D'abramo, and M.N. Kutty. 2010. Freshwater prawn biology and farming. WileyBlackwell Science, Lowa, xiv + 531 pp.

Crab, R., Kochva, M., Verstraete, W., \& Avnimelech, Y. 2009a. Bioflocs technology application in over-wintering of tilapia. Aquacultural Engineering, 40: 105- 112.

Crab, R., Chielens, B., Wille, M., Bossier, P., \& Verstraete, W. $2009^{b}$. The effect of different carbon sources on the nutritional value of bioflocs, a feed for Macrobrachium rosenbergii postlarvae. Aquaculture Research, 2009, 1- 9.

Crab, R., Defoirdt, T., Bossier, P. , \& Verstraete, W. 2012. Biofloc technology in aquaculture: Beneficial effects and future challenges. Aquaculture, 356- 357 (2012): 351356

D'Abramo, L.R., Daniels, W.H., Fondren, M.W., \& Brunson, M.W. 1995. Management Practices for culture of freshwater prawn (Macrobrachium rosenbergii) intemperate climates. MAFES bulletin, 1030: $12 \mathrm{pp}$.

Fitter, R. \& Manuel, R. 1986. Collins field guide to freshwater life. Collins, London, $369 \mathrm{pp}$.

Holt, J.G., Krieg, N.r., Sneath, P.H.A., Staley, J.T., \& Williams, S.T. 1994. Bergey's manual of determinative bacteriology $9^{\text {th }}$. Williams \& Wilkins. Baltimore, $754 \mathrm{pp}$.

Khasani. 2006. Keragaan benih udang galah GIMacro pada wadah berbeda. Prosiding Sem. 2006 Hasil Penelitian Perikanan dan Nas. Tahunan III Kelautan, Fakultas Pertanian UGM. Jogjakarta.

Mallasen, M. \& Valenti, W.C. 2006. Effect of ni- 
trite on larval development of giant river prawn Macrobrachium rosenbergii. Aquaculture, 261: 1,292-1,298.

Mattjik, A.A. \& Sumentajaya, I.M. 2006. Perancangan percobaan dengan aplikasi SAS dan minitab Jilid I. IPB Press, Bogor, 275 hlm.

New, M.B. 1995. Status of freshwater prawn farming: a review. Aquaculture Research, 26: 1- 54.

New, M.B. 2002. Farming freshwater prawn. A manual for the culture of the giant river prawn (Macrobrachium rosenbergii). Italy, FAO Rome, $435 \mathrm{pp}$.

Noga, E.J. 2000. Fish disease, diagnosis and treatment. Lowa State University Press, Lowa, 339 pp.
Rohmana, D. 2008. Konversi limbah budidaya ikan lele, Clarias sp. menjadi biomassa bakteri heter otr of untuk perbaikan kualitas air dan makanan udang galah, Macrobrachium rosenbergii. Tesis. Institut Pertanian Bogor.

Summerfelt, S., William, J- B., \&Tsukuda, S. 2001. Controlled Systems: Water reuse and recirculation. Dalam: Wedemeyer, G.A.(ed). 2001. Fish hatchery management. $2^{\text {nd }} \mathrm{ed}$. American Fisheries Society, Bethesda, p. 285- 396.

Wynne, F. 2000. Grow-out culture of freshwater prawn in Kentucky. Kentucky State University Cooperative Extension Program, Graves Country Cooperative Extension Service, 9 pp. 